\title{
WYKORZYSTANIE ELEMENTÓW ANALIZY FINANSOWEJ DO OCENY KONDYCJI MIKROPRZEDSIĘBIORSTWA NA PODSTAWIE PODATKOWEJ KSIĘGI PRZYCHODÓW I ROZCHODÓW ORAZ OBLIGATORYJNYCH EWIDENCJI POMOCNICZYCH
}

\begin{abstract}
Funkcjonowanie w złożonej i konkurencyjnej gospodarce rynkowej ciagle stawia przed przedsiębiorstwami nowe wyzwania wymagające podejmowania wielu decyzji zarządczych. Decyzje te dotyczą między innymi profilu działalności, alokacji zasobów, źródeł finansowania, zakresu oferowanych produktów czy towarów, kierunków rozwoju i związanych $\mathrm{z}$ tym inwestycji. W dużej mierze wynik końcowy podejmowanych decyzji zarządczych zależy od oceny kondycji finansowej prowadzonego przedsiębiorstwa. $Z$ tego powodu w procesie decyzyjnym istotną rolę przypisuje się analizie finansowej, dzięki której możliwe są między innymi: ocena sytuacji majątkowej i finansowej przedsiębiorstwa, analiza efektywności prowadzonej działalności, ocena zdolności przedsiębiorstwa do rozwoju. Rozwiązywanie problemów decyzyjnych na ogół nie jest możliwe bez dostępu do użytecznych informacji finansowych, których podstawowym źródłem w przedsiębiorstwie są księgi rachunkowe. Jednak część mikroprzedsiębiorstw nie prowadzi ksiąg rachunkowych, gdyż zgodnie $\mathrm{z}$ obowiązującym prawem, ze względu na formę organizacyjno-prawną bądź osiagane przychody, nie ma takiego obowiązu. Mikroprzedsiębiorstwa te prowadzą jednak obligatoryjnie różne ewidencje dla celów rozliczeń publiczno-prawnych, których rodzaj zależy między innymi od wybranej formy rozliczeń $\mathrm{z}$ tytułu podatku dochodowego. Informacje $\mathrm{w}$ nich zawarte można również wykorzystać do celów zarządzania, chociaż w znacznie ograniczonym zakresie. Celem artykułu jest wskazanie możliwości wykorzystania informacji zawartych w podatkowej księdze przychodów i rozchodów oraz dodatkowych obligatoryjnych ewidencjach prowadzonych dla potrzeb rozliczeń publiczno-prawnych do oceny kondycji finansowej mikroprzedsiębiorstwa.

Słowa kluczowe: mikroprzedsiębiorstwo, ocena kondycji finansowej mikroprzedsiebiorstw, analiza finansowa
\end{abstract}

\section{WPROWADZENIE}

Obecnie, w erze gospodarki opartej na wiedzy jednym z kluczowych czynników sukcesu jest dostęp do użytecznych informacji, w tym informacji ekonomicznych. Trudno sobie wyobrazić podmioty funkcjonujące w gospodarce rynkowej, które mogłyby sobie pozwolić na skuteczne konkurowanie i długofalowy rozwój bez analizy konsekwencji finansowych podejmowanych decyzji. Można powiedzieć, że wraz z coraz trudniejszymi

\footnotetext{
1 Dr Sabina Rokita, Zakład Finansów i Bankowości, Wydział Zarządzania, Politechnika
} Rzeszowska, Al. Powstańców Warszawy 8, 35-959 Rzeszów 
warunkami funkcjonowania na rynku następuje wzmożone zainteresowanie wszelkimi koncepcjami i rozwiązaniami pozwalającymi doskonalić system informacyjny wspomagający zarządzanie podmiotem, w którym szczególne miejsce zajmują oczywiście informacje finansowe generowane przez system rachunkowości. Tworzeniu coraz bardziej rozbudowanych systemów informacyjnych wspomagających zarządzanie sprzyja również rozwój technologii informatycznych, bez których nie byłoby możliwe generowanie wielu informacji w odpowiednim czasie, przy zachowaniu rozsądnej relacji nakładu do uzyskanego efektu. Mimo to zdecydowana większość koncepcji czy rozwiązań w tym zakresie, opisywanych w literaturze przedmiotu bądź wdrażanych w praktyce, ma zastosowanie w średnich bądź dużych przedsiębiorstwach. Niewiele z nich natomiast może być wykorzystanych przez małe przedsiębiorstwa, a zwłaszcza mikroprzedsiębiorstwa, których zdecydowana większość, ze względu na osiaggane obroty ze sprzedaży czy też formę organizacyjno-prawną, nie ma obowiązku prowadzenia ksiąg rachunkowych. Księgi rachunkowe nie są co prawda warunkiem koniecznym do sprawnego funkcjonowania systemu informacyjnego wspomagającego zarządzanie, ale zwykle są jego bardzo istotnym elementem jako podstawowe źródło informacji finansowych w jednostce. Podmioty, które nie mają obowiązku prowadzenia ksiąg rachunkowych, prowadzą obligatoryjnie różne ewidencje stanowiące podstawę rozliczeń publiczno-prawnych. Umiejętne wykorzystanie informacji z nich pochodzących również może przynieść wiele korzyści w zarządzaniu mikroprzedsiębiorstwem, chociaż oczywiście ich przydatność w porównaniu z księgami rachunkowymi jest mocno ograniczona. Celem artykułu jest wskazanie możliwości wykorzystania informacji zawartych w podatkowej księdze przychodów i rozchodów oraz dodatkowych obligatoryjnych ewidencjach prowadzonych dla potrzeb rozliczeń publiczno-prawnych do oceny kondycji finansowej mikroprzedsiębiorstwa.

\section{ZNACZENIE INFORMACJI FINANSOWYCH W ZARZADZANIU MIKROPRZEDSIĘBIORSTWEM I ŹRÓDŁA ICH POZYSKANIA}

Jak dotąd nie wypracowano jednego, powszechnie obowiązującego kryterium klasyfikacji wielkości przedsiębiorstw - raczej używa się różnych kryteriów do różnych celów. Zgodnie z ustawą o swobodzie działalności gospodarczej za mikroprzedsiębiorcę uważa się przedsiębiorcę, który w co najmniej jednym z dwóch ostatnich lat obrotowych ${ }^{2}$ :

1. zatrudniał średniorocznie mniej niż 10 pracowników oraz

2. osiagną̧ roczny obrót netto ze sprzedaży towarów, wyrobów i usług oraz operacji finansowych nieprzekraczający równowartości w złotych 2 milionów euro lub sumy aktywów jego bilansu sporządzonego na koniec jednego $\mathrm{z}$ tych lat nie przekroczyły równowartości w złotych 2 milionów euro.

Można w zasadzie zaryzykować stwierdzenie, że mikroprzedsiębiorcy, działając na rynku, mimo niewielkiej skali działalności, zasadniczo zmagają się $\mathrm{w}$ obszarze zarządzania z podobnymi dylematami co pozostali jego uczestnicy. Muszą zatem nieustannie rozwiązywać problemy i podejmować decyzje dotyczące profilu działalności, alokacji zasobów, źródeł finansowania, zakresu oferowanych produktów czy towarów, kierunków rozwoju i związanych $\mathrm{z}$ tym inwestycji, oceniać kondycję finansową prowadzonego przedsiębiorstwa itd.

\footnotetext{
${ }^{2}$ Ustawa z 2 lipca 2004 roku o swobodzie działalności gospodarczej (DzU 2004 nr 173, poz. 1807
} ze zm., art. 104). 
Jak już wspomniano, podstawowym źródłem informacji finansowych są księgi rachunkowe, które odpowiednio dostosowane do specyfiki działalności i potrzeb zarządzania dobrze spełniają swoją funkcję. Dostarczają zatem na bieżąco informacji, na których podstawie są możliwe analiza finansowa jednostki, a także rozwiązywanie różnych problemów decyzyjnych. Jednak znaczna część mikroprzedsiębiorstw jest prowadzona $\mathrm{w}$ formie działalności gospodarczych osób fizycznych, których ani forma organizacyjno-prawna, ani osiagane przychody roczne nie obligują do prowadzenia ksiąg rachunkowych. Zgodnie $\mathrm{z}$ ustawą o rachunkowość księgi rachunkowe obligatoryjnie prowadzą bowiem osoby fizyczne, spółki cywilne osób fizycznych, spółki jawne osób fizycznych oraz spółki partnerskie, jeżeli ich przychody netto ze sprzedaży towarów, produktów i operacji finansowych za poprzedni rok obrotowy wyniosły co najmniej równowartość w walucie polskiej 1200000 euro $^{3}$. Gdy warunek ten nie jest spełniony, przedsiębiorca może prowadzić księgi rachunkowe dobrowolnie, po uprzednim zawiadomieniu o tym właściwego naczelnika urzędu skarbowego. Należy pamiętać, że gdy przedsiębiorca się na takie rozwiązanie nie zdecyduje, pociąga to za sobą określone konsekwencje pod względem możliwości pozyskania informacji dla celów zarządzania, a wasadzie znacznie te możliwości ogranicza. W takiej sytuacji rozwiązania są następujące:

1. wykorzystywanie dla potrzeb zarządzania wyłącznie informacji pochodzących $\mathrm{z}$ obligatoryjnych ewidencji stanowiących podstawę rozliczeń publicznoprawnych, głównie z tytułu podatku dochodowego;

2. wykorzystywanie dla potrzeb zarządzania informacji pochodzących z obligatoryjnych ewidencji stanowiących podstawę rozliczeń publiczno-prawnych oraz uzupełnianie ich o ewidencje dodatkowe prowadzone wyłącznie dla celów zarządczych;

3. stworzenie systemu wspierającego zarządzanie, generującego również informacje finansowe, całkowicie niezależnego od ewidencji prowadzonych dla potrzeb rozliczeń publiczno-prawnych.

$\mathrm{Na}$ stworzenie niezależnego systemu informacyjnego wspierającego zarządzanie, podobnie zresztą jak na dobrowolne prowadzenie ksiąg rachunkowych, decydują się na ogół ci mikroprzedsiębiorcy, których działalności prosperują wystarczająco dobrze, by mogli sobie na to pozwolić. Zwykle takie rozwiązania są bowiem dość kosztowne, gdyż wymagają zakupu odpowiedniego oprogramowania, zapewnienia jego serwisu, często też zatrudnienia dodatkowych osób do jego obsługi (wprowadzania, generowania i analizy informacji) $\mathrm{i}$ w związku $\mathrm{z}$ tym zdarza się, że ich prowadzenie nie ma uzasadnienia ekonomicznego, to znaczy koszty utrzymania są wyższe niż uzyskane efekty. Dlatego też mikroprzedsiębiorcy, którzy działają na niewielką skalę, zatrudniają kilka osób, a nierzadko prowadzą biznes samodzielnie bądź też przy pomocy członków rodziny, zwykle pozostają przy prowadzeniu obligatoryjnych ewidencji stanowiących podstawę rozliczeń publiczno-prawnych. Wtedy rodzaj prowadzonych ewidencji często zależy ściśle od wyboru formy rozliczeń z tytułu podatku dochodowego od osób fizycznych. Generalnie osoba fizyczna prowadząca działalność gospodarcza, zakładajac, że spełnia kryteria wskazane przez określone przepisy, może wybrać: zryczałtowane formy rozliczeń $\mathrm{z}$ tytułu podatku dochodowego (karta podatkowa, ryczałt od przychodów

\footnotetext{
${ }^{3}$ Ustawa z 29 września 1994 r. o rachunkowości, DzU 1994 nr 121, poz. 591, ze zm., art. 2 ust. 1
} pkt. 2. 
ewidencjonowanych), które regulują Ustawa z 20 listopada 1998 r. o zryczałtowanym podatku dochodowym od niektórych przychodów osiaganych przez osoby fizyczne, albo zasady ogólne (podatek według skali bądź stałej stawki 19\%), które reguluje Ustawa z 26 lipca 1991 r. o podatku dochodowym od osób fizycznych. Wspomniane akty prawne w dużej mierze determinują również obowiązki ewidencyjne podatników i tak w wypadku:

- karty podatkowej - prowadzi się ewidencję zatrudnienia, karty przychodów zatrudnianych osób oraz przechowuje się wydane za żądanie klienta rachunki i faktury potwierdzające sprzedaż;

- ryczałtu od przychodów ewidencjonowanych - prowadzi się ewidencję środków trwałych oraz wartości niematerialnych i prawnych, ewidencję wyposażenia, ewidencję przychodów ze sprzedaży, karty przychodów zatrudnianych osób oraz przechowuje się dowody zakupu towarów;

- zasad ogólnych (podatek według skali bądź stałej stawki 19\%) - prowadzi się ewidencję środków trwałych oraz wartości niematerialnych i prawnych, ewidencję wyposażenia, karty przychodów zatrudnianych osób oraz podatkową księgę przychodów i rozchodów (KPIR) oraz przechowuje się wszelkie dokumenty stanowiące podstawę zapisu w tej księdze.

Niewątpliwie najwięcej informacji finansowych o prowadzonej działalności można uzyskać zewidencji prowadzonych przy rozliczaniu się z podatku dochodowego na zasadach ogólnych, o czym w zasadzie przesądza prowadzenie podatkowej księgi przychodów i rozchodów.

\section{KSIĘGA PRZYCHODÓW I ROZCHODÓW ORAZ EWIDENCJE DODATKOWE JAKO ŹRÓDŁO INFORMACJI DO ANALIZY KONDYCJI FINANSOWEJ MIKROPRZEDSIĘBIORSTWA}

Zasady prowadzenia podatkowej księgi przychodów i rozchodów reguluje Rozporządzenie Ministra Finansów z 26 sierpnia 2003 r. w sprawie prowadzenia podatkowej księgi przychodów i rozchodów, a której wzór przedstawiono w tabeli 1 . KPIR składa się z 16 kolumn, przy czym:

- kolumny 1-6 zawierają dane dotyczące kontrahentów oraz treść operacji gospodarczych;

- w kolumnie 7 wykazuje się wyłącznie przychody z tytułu sprzedaży produktów (wyrobów gotowych i usług), towarów i materiałów;

- w kolumnie 8 wykazuje się pozostałe przychody, niemieszczące się w kategorii przychodów z tytułu sprzedaży produktów, towarów i materiałów, na przykład: sprzedaż środków trwałych, wyposażenia, otrzymane kary od kontrahentów z tytułu opóźnień w dostawie towarów;

- kolumna 9 to łączna kwota przychodów z kolumn 7 i 8;

- w kolumnie 10 wykazuje się wartość zakupionych towarów i materiałów w cenach zakupu;

- kolumna 11 zawiera koszty uboczne zakupu towarów i materiałów, na przykład transport, ubezpieczenie, załadunek, rozładunek;

- w kolumnie 12 wykazuje się koszty wynagrodzeń;

- w kolumnie 13 wykazuje się pozostałe koszty prowadzenia działalności, niemieszczące się w kategoriach wykazywanych w kolumnach 10-12, na przykład: czynsz za lokal, opłaty za energię elektryczna, gaz, wodę, ogrzewanie, opłaty za 
usługi telekomunikacyjne, zakup paliw, wydatki dotyczące remontów, amortyzację środków trwałych;

- kolumna 14 to łączna kwota wydatków wykazanych w kolumnach 12 i 13;

- kolumny 15 i 16 mają charakter pomocniczy.

Tabela 1. Wzór podatkowej księgi przychodów i rozchodów.

\begin{tabular}{|c|c|c|c|c|c|c|c|c|}
\hline \multirow[b]{2}{*}{ L.p. } & \multirow[b]{2}{*}{$\begin{array}{l}\text { Data zdarz. } \\
\text { gospod. }\end{array}$} & \multirow[b]{2}{*}{$\begin{array}{c}\mathrm{Nr} \\
\text { dowodu } \\
\text { księg. }\end{array}$} & \multicolumn{2}{|c|}{ Kontrahent } & \multirow[b]{2}{*}{$\begin{array}{l}\text { Opis zdarz. } \\
\text { gospod. }\end{array}$} & \multicolumn{3}{|c|}{ Przychód } \\
\hline & & & $\begin{array}{c}\text { Imię i } \\
\text { nazwisko }\end{array}$ & Adres & & $\begin{array}{l}\text { Wartość } \\
\text { sprzedanych } \\
\text { towarów } \\
\text { i usług }\end{array}$ & $\begin{array}{l}\text { Pozostałe } \\
\text { przychody }\end{array}$ & $\begin{array}{c}\text { Razem } \\
\text { przychód } \\
(7+8)\end{array}$ \\
\hline 1 & 2 & 3 & 4 & 5 & 6 & 7 & 8 & 9 \\
\hline & & & & & Suma strony & & & \\
\hline & & & & & $\begin{array}{l}\text { Przeniesienie } \\
\text { z poprzedniej } \\
\text { strony }\end{array}$ & & & \\
\hline & & & & & $\begin{array}{l}\text { Razem od } \\
\text { początku } \\
\text { roku }\end{array}$ & & & \\
\hline
\end{tabular}

\begin{tabular}{|c|c|c|c|c|c|c|}
\hline \multirow{2}{*}{$\begin{array}{c}\text { Wartość towarów } \\
\text { handlowych } \\
\text { i materiałów } \\
\text { wg cen zakupu }\end{array}$} & \multirow[b]{2}{*}{$\begin{array}{c}\text { Koszty } \\
\text { uboczne } \\
\text { zakupu }\end{array}$} & \multicolumn{4}{|c|}{ Wydatki (koszty) } & \multirow[b]{2}{*}{ Uwag } \\
\hline & & $\begin{array}{c}\text { Wynagrodzenia } \\
\text { w gotówce } \\
\text { i naturze }\end{array}$ & $\begin{array}{c}\text { Pozostałe } \\
\text { wydatki }\end{array}$ & $\begin{array}{c}\text { Razem } \\
\text { wydatki (12 } \\
+13)\end{array}$ & & \\
\hline 10 & 11 & 12 & 13 & 14 & 15 & 16 \\
\hline & & & & & & \\
\hline & & & & & & \\
\hline & & & & & & \\
\hline
\end{tabular}

Źródło: opracowanie własne na podstawie Rozporządzenia Ministra Finansów z 26 sierpnia 2003 r. w sprawie prowadzenia podatkowej księgi przychodów i rozchodów, załącznik nr 1, DzU 2003 nr 152, poz. 1475 ze zm.

Biorąc pod uwagę konstrukcję podatkowej księgi przychodów i rozchodów, należy zauważyć, że możliwości generowania z niej informacji dla celów zarządzania są bardzo ograniczone. Jest to poniekąd oczywiste, gdyż nie jest to jej podstawowa funkcja. Należy bowiem pamiętać, że głównym celem podatkowej księgi przychodów i rozchodów jest dostarczenie informacji do prawidłowego ustalenia dochodu do opodatkowania w myśl ustawy o podatku dochodowym od osób fizycznych.

Wśród najważniejszych ograniczeń wynikających z możliwości wykorzystania informacji pochodzących z KPIR dla celów zarządzania należy wskazać:

- zbytnio zagregowane dane w kolumnach dotyczących przychodów (kol. 7 i 8 KPIR), na przykład przychody ze sprzedaży produktów, towarów i materiałów 
wykazywane są w jednej kwocie bez możliwości ich podziału według innych kryteriów, takich jak: rodzaje produktów, towarów i materiałów, kontrahenci itd.;

- zbytnio zagregowane dane w kolumnach dotyczących kosztów (kol. 10-13 KPIR), na przykład brak możliwości ich podziału według innych kryteriów, takich jak rodzaj kosztu, koszty wytworzenia produktów, koszty działań, miejsca powstawania kosztów itd. Ponadto należy zwrócić uwagę na zawartość kolumny 10 KPIR Zakup towarów handlowych i materiałów wedtug cen zakupu, gdyż w trakcie roku umownie w koszty uzyskania przychodu zalicza się całą jej zawartość, bez uwzględnienia stanu zapasów. Odpowiedniej korekty o stany magazynowe wartości zakupionych towarów handlowych i materiałów dokonuje się dopiero z końcem roku podatkowego, uwzględniając spis z natury na początek i koniec danego roku. W praktyce może to oznaczać, że w trakcie roku podatkowego, przy dużych wahaniach stanów magazynowych, traktowanie w całości wartości wskazanych w kolumnie 10 Zakup towarów handlowych i materiałów wedtug cen zakupu jako kosztów do celów zarządczych może prowadzić do wyciąnięcia niewłaściwych wniosków;

- wykazywanie w KPIR wyłącznie przychodów i kosztów spełniających warunki wskazane przez ustawę o podatku dochodowym od osób fizycznych. Problem ten dotyczy zwłaszcza kosztów, gdyż w KPIR wykazuje się tak zwane koszty uzyskania przychodu, które są zwykle katalogiem węższym od kosztów działalności w sensie ekonomicznym, co w konsekwencji powoduje, że dochód do opodatkowania jest większy od rzeczywistego zysku przedsiębiorcy;

- konsekwencją zbytnich agregacji danych dotyczących przychodów i kosztów jest brak możliwości ustalenia rentowności sprzedawanych towarów i produktów według wybranych kryteriów. Może to stanowić szczególny problem, gdy działalność przedsiębiorstwa jest zróżnicowana zarówno pod względem rodzaju prowadzonej działalności (produkcja, handel, usługi), jak i oferowanego asortymentu;

- przedsiębiorcy prowadzący KPIR nie mają obowiązku rejestracji operacji związanych $\mathrm{z}$ obrotem środkami pieniężnymi oraz rejestracji rozrachunków z odbiorcami i dostawcami, co znacznie utrudnia zarządzanie należnościami i zobowiązaniami oraz płynnością finansową. Zmiany przepisów od 1 stycznia 2013 r. zarówno w podatku dochodowym, jak i podatku od towarów i usług wymusiły co prawda analizę opóźnień w terminach płatności zobowiązań, jednak obowiązki te nie są wystarczające, aby informacje dzięki nim uzyskane stanowiły podstawę do efektywnego zarządzania płynnością finansową;

- przedsiębiorcy prowadzący podatkową KPIR nie mają obowiązku prowadzenia szczegółowej ewidencji zapasów, co znacznie utrudnia śledzenie stanów magazynowych materiałów, towarów czy wyrobów gotowych, zwłaszcza w trakcie roku obrotowego. $\mathrm{Na}$ koniec roku podatkowego jest jednak obowiązek sporządzenia spisu z natury i wyceny zapasów;

- przy KPIR istnieje obowiązek prowadzenia ewidencji środków trwałych i wartości niematerialnych i prawnych (co pozwala ustalić stan tych środków, stopień ich zużycia i wielkość odpisów amortyzacyjnych) oraz ewidencji wyposażenia, obejmującej rzeczowe składniki majątku powiązane z prowadzoną działalnością, 
które nie są zaliczone do środków trwałych, a których wartość początkowa jest większa od $1500 \mathrm{zł}$, ale nie przekracza $3500 \mathrm{zł.}$

Mimo wskazanych ograniczeń, wykorzystując informacje pochodzące z KPIR, można dokonać oceny kondycji finansowej mikroprzedsiębiorstwa czy też wspomóc zarządzających w rozwiązywaniu wielu problemów decyzyjnych.

W literaturze przedmiotu szczególne miejsce procesie decyzyjnym przypisuje się analizie finansowej, która umożliwia diagnozę różnych zjawisk, określanie przyczyn i czynników je kształtujących, a także skutków zachodzących zmian. Odgrywa więc istotną rolę $\mathrm{w}$ generowaniu informacji o sytuacji finansowej przedsiębiorstwa $\mathrm{i}$ ma ogromne walory poznawcze nie tylko w ujęciu retrospektywnym bazującym na zdarzeniach przeszłych, ale także prospektywnym, dostarczając podstaw do podejmowania decyzji ${ }^{4}$. Generalnie rzecz ujmując, można powiedzieć, że analiza finansowa obejmuje swoim zakresem ocenę sytuacji majątkowej i finansowej przedsiębiorstwa, analizę efektywności prowadzonej działalności, ocenę zdolności przedsiębiorstwa do rozwojus ${ }^{5}$. Zatem zastosowanie narzędzi analizy finansowej pozwala na uzyskanie użytecznych informacji między innymi z obszaru:

- rentowności działalności w różnych przekrojach;

- stanu i struktury majątku oraz źródeł finansowania;

- płynności finansowej oraz stanu zobowiązań i należności z różnych tytułów;

- sprawności działania i efektywności wykorzystania zasobów;

- stopnia zadłużenia jednostki i jej zdolności do spłaty długu.

Warto jednak pamiętać, że podstawowymi wewnętrznymi źródłami danych wykorzystywanych $\mathrm{w}$ analizie finansowej przedsiębiorstwa są sprawozdania finansowe oraz zapisy w księgach rachunkowych, co też znajduje swoje odzwierciedlenie w konstrukcji wielu wskaźników. Możliwości generowania informacji finansowych z tych źródeł są nieporównywalnie większe niż z KPIR czy też pozostałych ewidencji prowadzonych dla celów rozliczeń publiczno-prawnych. Dlatego też możliwości wykorzystania narzędzi analizy finansowej $w$ ocenie kondycji finansowej mikroprzedsiębiorstw wyłącznie na podstawie KPIR oraz pozostałe ewidencje prowadzone dla celów rozliczeń publiczno-prawnych są znacznie ograniczone. Niemniej jednak wykorzystując nawet wybrane elementy analizy finansowej, takie jak analiza struktury przychodów i kosztów, rentowności przychodów i kosztów, sprawności działania, dynamiki zmian $\mathrm{w}$ wybranym okresie, można uzyskać cenne informacje przydatne w zarządzaniu mikroprzedsiębiorstwem.

\subsection{Struktura przychodów i kosztów}

Ustalenie struktury przychodów i kosztów polega na obliczeniu udziału poszczególnych grup przychodów w przychodach ogółem oraz udziału poszczególnych grup kosztów w kosztach ogółem. Przykładowe wielkości, które można policzyć na podstawie podatkowej KPIR, zaprezentowano w tabeli 2.

\footnotetext{
${ }^{4}$ W. Gabrusewicz, Analiza finansowa. Teoria i zastosowanie, PWE, Warszawa 2014, s. 9.

${ }^{5}$ Ibidem, s. 22.
} 
Tabela 2. Wskaźniki struktury przychodów i kosztów

\begin{tabular}{|l|l|}
\hline \multicolumn{2}{|c|}{ Struktura przychodów } \\
\hline $\begin{array}{l}\text { Udział przychodów ze sprzedaży produktów } \\
\text { towarów i materiałów w przychodach ogółem }\end{array}$ & $\begin{array}{l}\text { Przychody ze sprzedaży produktów, towarów } \\
\text { i materiałów (kol. 7 KPIR)/przychody ogółem } \\
\text { (kol. 9 KPIR) }\end{array}$ \\
\hline $\begin{array}{l}\text { Udział pozostałych przychodów } \\
\text { w przychodach ogółem }\end{array}$ & $\begin{array}{l}\text { Pozostałe przychody (kol. 8 KPIR)/przychody } \\
\text { ogółem (kol. 9 KPIR) }\end{array}$ \\
\hline \multicolumn{2}{|c|}{ Struktura kosztów } \\
\hline $\begin{array}{l}\text { Udział wartości sprzedanych towarów } \\
\text { i materiałów w cenach zakupu w kosztach } \\
\text { ogółem }\end{array}$ & $\begin{array}{l}\text { Wartość sprzedanych towarów i materiałów } \\
\text { w cenach zakupu'/koszty ogółem }\end{array}$ \\
\hline $\begin{array}{l}\text { Udział kosztów ubocznych zakupu w kosztach } \\
\text { ogółem }\end{array}$ & $\begin{array}{l}\text { Koszty uboczne zakupu (kol. 11 KPIR)/koszty } \\
\text { ogółem }\end{array}$ \\
\hline $\begin{array}{l}\text { Udział kosztów wynagrodzeń w kosztach } \\
\text { ogółem }\end{array}$ & $\begin{array}{l}\text { Koszty wynagrodzeń (kol. 12 KPIR)/koszty } \\
\text { ogółem }\end{array}$ \\
\hline $\begin{array}{l}\text { Udział pozostałych kosztów w kosztach } \\
\text { ogółem }\end{array}$ & Pozostałe koszty (kol. 13 KPIR)/koszty ogółem \\
\hline \multicolumn{2}{|c|}{ Relacje między kosztami a przychodami } \\
\hline $\begin{array}{l}\text { Udział wartości sprzedanych towarów } \\
\text { i materiałów w przychodach ze sprzedaży } \\
\text { produktów, towarów i materiałów }\end{array}$ & $\begin{array}{l}\text { Wartość sprzedanych towarów i materiałów } \\
\text { w cenach zakupu/przychody ze sprzedaży } \\
\text { produktów, towarów i materiałów (kol. 7 KPIR) }\end{array}$ \\
\hline $\begin{array}{l}\text { Zródło: opracowanie własne na podstawie } \\
i \text { zastosowanie, PWE, Warszawa 2014, s. 198-216. Gabrusewicz, Analiza finansowa. Teoria }\end{array}$
\end{tabular}

Ustalenie struktury znacznie ułatwia analizy i porównania zmian poszczególnych grup przychodów czy kosztów w czasie, śledzenie relacji między nimi, na przykład:

- analizując strukturę przychodów, można ocenić, czy przedsiębiorstwo koncentruje się na swojej podstawowej działalności - wtedy udział przychodów ze sprzedaży towarów i materiałów w przychodach ogółem powinien być większy niż udział pozostałych przychodów w przychodach ogółem;

- analizując strukturę kosztów, można dokonać rankingu grup kosztów według wielkości ich udziału w kosztach ogółem;

- systematyczne liczenie struktury przychodów i kosztów w określonych odstępach czasu pozwala na dokonanie porównań i śledzenie trendu zmian, zarówno w ramach poszczególnych grup, jak i pomiędzy grupami.

Bardzo ważną informację można również uzyskać, licząc udział wartości sprzedanych materiałów i towarów w cenach zakupu w przychodach ze sprzedaży towarów i materiałów, ponieważ porównując go z jednością, można ustalić średnią marżę realizowaną na sprzedaży $\mathrm{z}$ działalności podstawowej. Im mniejsza wartość tego

\footnotetext{
${ }^{6}$ Wartość sprzedanych towarów i materiałów w cenach zakupu $=$ kol. $10 \mathrm{KPIR}+$ wartość spisu z natury zapasów na początek roku podatkowego - wartość spisu z natury zapasów na koniec roku podatkowego. $\mathrm{W}$ trakcie roku podatkowego często pomija się wartość spisu z natury zapasów i w uproszczeniu przyjmuje się, że wartość sprzedanych towarów i materiałów w cenach zakupu jest równa wartości zakupionych towarów i materiałów w cenach zakupu (kol. $10 \mathrm{KPIR}$ ).

${ }^{7}$ Pojęcie kosztów ogółem ustalanych na podstawie KPIR należy utożsamiać z kosztami uzyskania przychodu, których sposób ustalania w trakcie roku podatkowego i na koniec roku podatkowego zaprezentowano w tabeli 3.
} 
wskaźnika, tym większą marżę realizuje przedsiębiorstwo, a więc tym sytuacja jest korzystniejsza.

\subsection{Rentowność przychodów i kosztów}

Rentowność generalnie wyraża relację osiagniętych efektów do jednostki nakładów, a więc im wyższe wartości osiągają wskaźniki rentowności, tym lepiej. Przykładowe wskaźniki rentowności, które można policzyć na podstawie KPIR, zaprezentowano w tabeli 3 .

Tabela 3. Wskaźniki rentowności

\begin{tabular}{|l|l|}
\hline \multicolumn{2}{|c|}{ Rentowność działalności } \\
\hline Rentowność przychodów ogółem & Dochód/przychody ogółem (kol. 9 KPIR) \\
\hline Rentowność przychodów ze sprzedaży & $\begin{array}{l}\text { Dochód/przychody ze sprzedaży materiałów } \\
\text { i towarów (kol. 7 KPIR) }\end{array}$ \\
\hline Rentowność kosztów ogółem & Dochód/koszty ogółem \\
\hline $\begin{array}{l}\text { Rentowność kosztów sprzedanych towarów } \\
\text { i materiałów }\end{array}$ & $\begin{array}{l}\text { Dochód/wartość sprzedanych towarów } \\
\text { i materiałów }\end{array}$ \\
\hline
\end{tabular}

Źródło: opracowanie własne na podstawie W. Gabrusewicz, Analiza finansowa. Teoria i zastosowanie, PWE, Warszawa 2014, s. 296-310.

Przy obliczaniu i interpretacji wskaźników rentowności na podstawie KPIR komentarza wymaga pojęcie dochodu. Dochód jest ustalany jako różnica między przychodami podatkowymi a kosztami uzyskania przychodu. Procedura liczenia kosztów uzyskania przychodu może jednak wyglądać nieco inaczej w trakcie roku podatkowego, a inaczej na koniec roku, co przedstawiono w tabeli 4.

Tabela 4. Ustalanie kosztów uzyskania przychodu

\begin{tabular}{|l|l|}
\hline $\begin{array}{c}\text { Koszty uzyskania przychodu w trakcie roku } \\
\text { podatkowego }\end{array}$ & $\begin{array}{l}\text { Koszty uzyskania przychodu na koniec roku } \\
\text { podatkowego }\end{array}$ \\
\hline- & $\begin{array}{l}\text { Wartość spisu z natury na poczatek roku } \\
\text { podatkowego }\end{array}$ \\
\hline $\begin{array}{l}\text { Zakup towarów handlowych i materiałów } \\
\text { (kol. 10 KPIR) }\end{array}$ & $\begin{array}{l}\text { Plus zakup towarów handlowych i materiałów } \\
\text { (kol. 10 KPIR) }\end{array}$ \\
\hline Plus koszty uboczne zakupu (kol. 11 KPIR) & Plus koszty uboczne zakupu (kol. 11 KPIR) \\
\hline- & $\begin{array}{l}\text { Minus } \text { wartość spisu z natury na koniec roku } \\
\text { podatkowego }\end{array}$ \\
\hline $\begin{array}{l}\text { Plus wynagrodzenia w gotówce i naturze } \\
\text { (kol. 12 KPIR) }\end{array}$ & $\begin{array}{l}\text { Plus wynagrodzenia w gotówce i naturze } \\
\text { (kol. 12 KPIR) }\end{array}$ \\
\hline Plus pozostałe wydatki (kol. 14 KPIR) & Plus pozostałe wydatki (kol. 14 KPIR) \\
\hline
\end{tabular}

Źródło: opracowanie własne na podstawie Rozporządzenia Ministra Finansów z 26 sierpnia 2003 r. w sprawie prowadzenia podatkowej księgi przychodów i rozchodów, załącznik 1.

Z tabeli 4 wynika, że pozycją różnicującą ustalanie dochodu w trakcie i na koniec roku podatkowego jest spis z natury zapasów. Gdy jednostka sporządza spis z natury wyłącznie na koniec roku podatkowego, to w trakcie roku w koszty uzyskania przychodu umownie zalicza całą wartość zakupionych materiałów i towarów. Należy zatem mieć to na uwadze przy interpretacji wskaźników rentowności liczonych w trakcie roku, zwłaszcza gdy 
wartość spisu $\mathrm{z}$ natury ulega znacznym wahaniom na początek i koniec roku podatkowego.

\subsection{Sprawność działania}

Wskaźniki sprawności działania pozwalają określić, jak efektywnie jednostka wykorzystuje swoje zasoby, ponieważ wpływa to na osiaggane przez nią efekty. Przykładowe wielkości, które można policzyć na podstawie KPIR zaprezentowano w tabeli 5.

Tabela 5. Wskaźniki sprawności działania

\begin{tabular}{|l|l|}
\hline \multicolumn{2}{|c|}{ Sprawność działania } \\
\hline Wskaźnik wydajności kosztów wynagrodzeń & $\begin{array}{l}\text { Przychody ze sprzedaży produktów, towarów } \\
\text { i materiałów (kol. 7 KPIR)/przeciętna wartość } \\
\text { kosztów wynagrodzeń (kol. 12 KPIR) }\end{array}$ \\
\hline Wskaźnik wydajności środków trwałych & $\begin{array}{l}\text { Przychody ze sprzedaży produktów, towarów } \\
\text { i materiałów (kol. 7 KPIR)/przeciętna wartość } \\
\text { środków trwałych }\end{array}$ \\
\hline $\begin{array}{l}\text { Cykl inkasa należności z tytułu dostaw i usług } \\
\text { w dniach }\end{array}$ & $\begin{array}{l}\text { Należności z tytułu dostaw i usług * 365 } \\
\text { /przychody ze sprzedaży produktów, towarów } \\
\text { i materiałów (kol. 7 KPIR) }\end{array}$ \\
\hline $\begin{array}{l}\text { Cykl spłaty zobowiązań z tytułu dostaw i usług } \\
\text { w dniach }\end{array}$ & $\begin{array}{l}\text { Zobowiązania z tytułu dostaw i usług * 365 } \\
\text { /przychody ze sprzedaży produktów, towarów } \\
\text { i materiałów (kol. 7 KPIR) }\end{array}$ \\
\hline
\end{tabular}

Źródło: opracowanie własne na podstawie na podstawie W. Gabrusewicz, Analiza finansowa. Teoria i zastosowanie, PWE, Warszawa 2014, s. 351-357.

Zaprezentowanych w tabeli 5 wskaźników nie można policzyć opierając się wyłącznie na danych pochodzących z KPIR, ale można je uzyskać z innych obligatoryjnych ewidencji:

- informacje o liczbie osób zatrudnionych można uzyskać z kart przychodów osób zatrudnionych;

- informacje o wartości środków trwałych można uzyskać z ewidencji środków trwałych;

- informacjami o stanie należności i zobowiązań z tytułu dostaw i usług po zmianie przepisów w 2013 r. powinna dysponować każda jednostka stosująca ustawę o podatku dochodowym czy ustawę o podatku od towarów i usług.

Wskaźnik wydajności kosztów wynagrodzeń będzie informował o wielkości przychodów wypracowanych przez jednostkę kosztów wynagrodzeń, więc im wyższe wielkości będzie wykazywał, tym korzystniej dla przedsiębiorstwa. Podobnie należy interpretować wskaźnik wydajności środków trwałych.

Cykl inkasa należności z tytułu dostaw i usług w dniach będzie informował, ile dni upływa od momentu powstania należności z tytułu sprzedaży produktów, towarów czy usług do momentu wpływu gotówki. Cykl spłaty zobowiązań z tytułu dostaw i usług w dniach będzie informował, ile dni upływa od momentu powstania zobowiązań z tytułu zakupu materiałów, towarów czy usług do momentu ich uregulowania. Długości cykli inkasa należności i spłaty zobowiązań, oprócz sytuacji samego przedsiębiorstwa, zależą

\footnotetext{
${ }^{8}$ Przeciętna wartość = $($ wartość na początek okresu + wartość na koniec okresu $) / 2$.
} 
też od branży, w której ono funkcjonuje. Generalnie pozytywnie ocenia się sytuację, kiedy cykl inkasa należności jest krótszy od cyklu spłaty zobowiązań. Wtedy w uproszczeniu można założyć, że zobowiązania są spłacane gotówką uzyskaną z należności, a więc w przedsiębiorstwie powinno być mniejsze zapotrzebowanie na obce źródła finansowania.

Mimo wielu ograniczeń, jakimi cechują się informacje, które można uzyskać z KPIR oraz innych obligatoryjnych ewidencji prowadzonych dla celów rozliczeń publicznoprawnych, systematyczne obliczanie na ich podstawie i analiza wybranych wskaźników w założonych okresach (miesięcznych, kwartalnych, rocznych), w połączeniu ze śledzeniem trendu ich zmian w czasie, pozwoli mikroprzedsiębiorcom zdiagnozować finansową kondycję ich przedsiębiorstwa oraz kierunki jej zmian w wybranym okresie. Pominięcie tych informacji w zarządzaniu mikroprzedsiębiorstwem z pewnością nie będzie dobrym posunięciem.

\section{ZAKOŃCZENIE}

Informacje finansowe $\mathrm{w}$ zarządzaniu przedsiębiorstwem mają kluczowe znaczenie. Na ich niedostatek często skarżą się właściciele mikroprzedsiębiorstw, w których prowadzi się KPIR. Przyczyn takiego stanu rzeczy jest kilka, a wśród najważniejszych należy wskazać nastawienie tej formy ewidencji na realizację celu fiskalnego, a więc prawidłowego ustalenia dochodu do opodatkowania. $\mathrm{Z}$ kolei jednak $\mathrm{z}$ tego właśnie powodu informacje pochodzace $\mathrm{z}$ KPIR oraz innych obligatoryjnych ewidencji pomocniczych prowadzonych dla celów rozliczeń publiczno-prawnych są niedoceniane i bywa, że są całkowicie pomijane przy podejmowaniu decyzji zarządczych. Nie jest to jednak podejście właściwe, bo nawet przy niedoskonałościach ewidencje te moga stanowić cenne źródło informacji, które umiejętnie wykorzystane ułatwią zarządzanie mikroprzedsiębiorstwem. Wskazane problemy mogą znacznie ograniczyć bądź nawet wyeliminować podatnicy, którzy prowadzą księgi rachunkowe zgodnie z ustawą o rachunkowości, poprzez odpowiednie dopasowanie do potrzeb jednostki polityki rachunkowości i struktury kont księgowych. W związku z tym przedsiębiorcy prowadzący podatkową księgę przychodów i rozchodów, którzy chcą zwiększyć efektywność wykorzystania informacji finansowych w zarządzaniu, mogą między innymi zdecydować się na dobrowolne prowadzenie ksiąg rachunkowych bądź wdrożyć pozaksięgowe oprogramowanie wspomagające generowanie informacji dla potrzeb zarządzania.

\section{LITERATURA}

[1] W. Gabrusewicz, Analiza finansowa. Teoria i zastosowanie, PWE, Warszawa 2014.

[2] Ustawa z 26 lipca 1991 r. o podatku dochodowym od osób fizycznych, DzU $1991 \mathrm{nr} 80$, poz. 350 ze zm.

[3] Ustawa z 2 lipca 2004 o swobodzie działalności gospodarczej, Dz.U. 2004 nr 173 poz. 1807 , ze zm.

[4] Ustawa z 29 września 1994 r. o rachunkowości, DzU 1994 nr 121, poz. 591 ze zm.

[5] Ustawa z 20 listopada 1998 r. o zryczałtowanym podatku dochodowym od niektórych przychodów osiaganych przez osoby fizyczne, DzU $1998 \mathrm{nr}$ 144, poz. $930 \mathrm{ze}$ zm. 
[6] Rozporządzenie Ministra Finansów z 26 sierpnia 2003 r. w sprawie prowadzenia podatkowej księgi przychodów i rozchodów, DzU 2003 nr 152, poz. 1475 ze zm.

\section{USING ELEMENTS OF FINANCIAL ANALYSIS FOR ESTIMATION OF FINANCIAL FORM OF MICROENTERPRISE IN FOOTHOLD ABOUT INFORMATION FROM TAX BOOK OF INCOME AND OUTGOINGS AND OTHER OBLIGATORY SUBSIDIARY RECORDS}

Functioning in complex and competitive market still puts new challenges before enterprises and require taking up many business decisions. These business decisions usually concentrate on profile of activity, stock's allocation, sources of funds, range of offered products, directions of development and connected with it investments. Many times final results of undertaken business decisions depend on estimate of financial form of led enterprise. Because of that in decision process a financial analysis plays an important role, due to which it is possible to evaluate condition of enterprises' assets and sources of funds, analyze efficiency of led activity, estimate an ability of enterprise for development. Solving of decision problems usually is not possible without an access to useful financial information whose basic source in enterprises are account books. However, some of microenterprises do not lead account books, because according to obligatory law, from the point of view of organizationally-legal form or achieved income, they do not have such a duty. These microenterprises lead different obligatory records for purposes of settlements of taxes and other state accounts, whose kind depends on chosen form of settlement of revenue tax accounts. Information included into them can be also used for making business decisions, but in considerably limited range. The purpose of this article is to shows possibilities of using information included in tax book of income and outgoings and other obligatory records leaded for purposes of settlements of taxes and other state accounts for estimation of financial form of microenterprises.

Keywords: microenterprise, estimate of financial form microenterprise, financial analysis.

DOI:10.7862/rz.2014.hss.28

Przesłano do redakcji: marzec 2014

Przyjęto do druku: lipiec 2014 